\title{
Review of economic reform in China: features, experiences and challenges
}

\section{Zhao Renwei}

In comparison to Eastern Europe and the former Soviet Union, economic reforms in China have some distinct characteristics. As noted by Harvard Professor Dwight $\mathrm{H}$. Perkins, there is a particularly Asian pattern of reform of socialist economic systems. According to this view, the reforming Asian economies have three characteristics: economic reform precedes political reform, the socialist countries in Asia are much poorer than their counterparts in Eastern Europe and the former Soviet Union, and the majority of people in Asian socialist countries are employed in the agricultural sector. Small and medium-sized enterprises account for the lion's share of industry output. Professor Perkins also points out that these three characteristics are closely related.

If China's particular social and economic environment is taken into account, economic reforms in China possess another three related characteristics. These can be summarised as follows. First, the degree to which the economic system derived from the former Soviet Union exerted influence on the Chinese economy varied from sector to sector. The sector that was most influenced was the backbone of the national economy, that is, those sectors that have been industrialised. The influence on the disaggregated agricultural sector and small industries was significantly less. Although the previous economic system in China could broadly be defined as a 'centrally planned (material) resource 
allocation system', its influence on the economy was confined to certain parts because of the influence of other factors such as low income. Some sectors of the economy were actually market oriented before reform (Ishikawa 1986). Some economists therefore use the term 'low coverage rate of the planned economy system' to describe this characteristic. This characteristic provided some support for the economic reforms in China.

Second, the economic reforms in China started from a highly centralised economy, differing from the reforms in Eastern Europe and the former Soviet Union. During the twenty years after the establishment of the centrally planned system (1956-78), there were some important changes. The economic system in 1978 (before reform) was more monotypic in ownership structure, more centralised in terms of decisionmaking and resource allocation, more demonetised in economic activities (more emphasis was placed on using material planning rather than the market mechanism to allocate resources) and more equal in income distribution. It was a closed economy and featured more flexibility in organising the economy than it had in the beginning of the centrally planned system. Although we may characterise the economic system before the reform as a conventional centralised economic system, it actually differed from a conventional one because it featured a supply system more in the style of militaristic communism. If the economic system in Eastern Europe and the former Soviet Union before reform was a typically centrally planned economy (Stalinist model), then the economic system in pre-reform China can be regarded as a model of quasi-militaristic communism. Figure 9.1 illustrates that reforms in China began at an earlier stage than reforms in the former Soviet Union and Eastern Europe.

So far we have only looked at the starting point of the reform by examining the economic system. If other factors outside the economic system are taken into consideration, such as the lack of theoretical guidance for reform and the lower level of economic development, the starting point of China's reform could have been much lower than that of the former Soviet Union and Eastern European countries.

Third, economic reform in China was more closely related to economic development than was the case in the former Soviet Union and Eastern Europe. The former countries had been industrialised and were regarded as developed countries before their reíorm, while China was still a developing country. China not only experienced a transition from a 
Figure 9.1 The starting point of economic reform in China

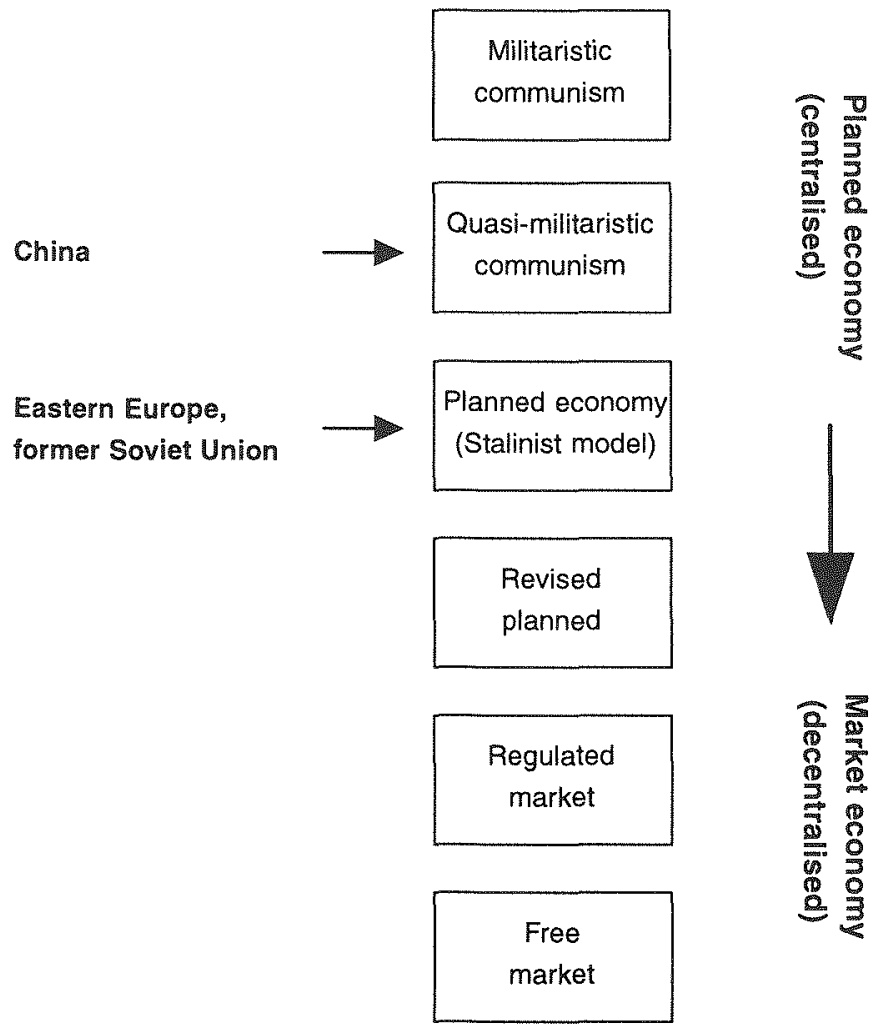

centrally planned to a market oriented economy, it also underwent a transformation in economic development from autarky economy to market economy. China underwent transformation from a dual economy to a modern economy (Figure 9.2).

In comparison to development transformation, the transition of an economic system is generally a more difficult process. This is because development transformation is a kind of natural evolution while the transition of an economic system depends on the instigation of reforms. 
Figure 9.2 China's transition of economic system and transformation of economic development

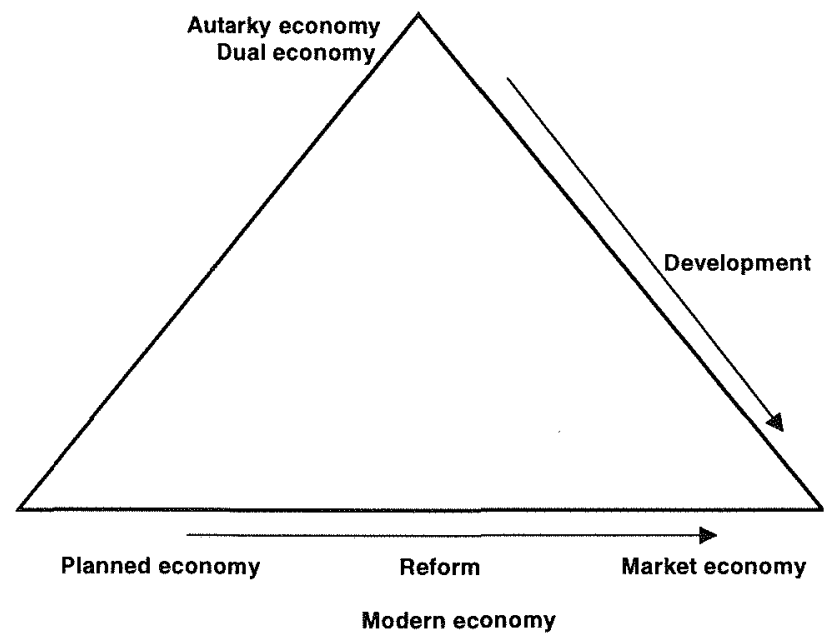

Further, the process of reform tends to encounter many man-made obstacles, mainly resulting from ideological problems and interest groups. Of course, people's cognitive process is not a straight line. This is another underlying reason that the reform process of the last twenty years has been complicated; the goal of economic reform is a typical example.

The reform process has experienced success and setbacks since the Third Plenum of the $11^{\text {th }}$ Central Planning Committee was held in December 1978. At the beginning of economic reform, the widely accepted view was that there was a need to introduce the market mechanism into the economic system, but there was no consensus on how far China should move along the path of marketisation. 'Marketoriented economists' did not totally abandon the idea of a centrally planned framework; advocates of a planned economy supported the proposed changes, but differed in their views on the extent of the role the market mechanism should play. 
However, as the reforms progressed, differences in the views of market and planned system economists widened. During 1981 and 1983, those who proposed to reduce the extent of central planning were criticised while those who argued that the market mechanism should play only a small role were very popular and their view was regarded as the goal of economic reform by the $12^{\text {th }}$ Central Planning Committee meeting. In retrospect, this was understandable. In the early 1980 s, people strongly appealed against the chaos experienced during the 'Cultural Revolution'. However, the theoretical preparation for reform was insufficient and China began by simply introducing reform theories from Eastern Europe. China had only recorded good economic growth figures in 1956 and 1965. The logical extension, therefore, was to continue to rely on the central plan but permit a limited role for the market mechanism. Although this mainstream thinking was challenged and would eventually be discarded, it remained influential in the formation of goals of economic reform for quite some time.

The Third Plenum of the $12^{\text {th }}$ Central Planning Committee, held in 1984 , formally put forward as the goal of economic reform a 'centrally planned commodity economy'. The main aim was to reduce the extent of compulsory planning. In 1987, the Central Planning Committee opted for indirect macroeconomic controls that 'government adjust and control the market, and the market guides the firm'. This approach represented quite a shock to the traditional centrally planned economic system and was an important step towards achieving the goal of market-oriented economic reform. This period (1984-88) can be regarded as the one in which the reform process advanced significantly.

Due to the failure of price reform in 1988 and the Tiananmen Square incident of 1989, reforms came to a standstill. The aforementioned indirect macroeconomic control disappeared in Party documents. It was replaced by the views that had prevailed ten years before: central planning should be the focus, and the market take on a subordinate role.

This retreat from market reform did not last long and its effects were minimal. It was halted by the ideas put forward by Deng Xiaoping when he travelled to southern China in 1992. Based on his ideas, the $14^{\text {th }}$ Central Planning Committee meeting in October 1992 made a socialist market economy the goal of reform.

Although China's economic reforms were market oriented from the beginning, it took about 14 years for the objective of the reforms to be clearly stated as 'market economy'. This does not imply that the debate 
about the goal of reform was finished after 1992. The argument remained in all debates that the essence of a socialist economy is a planned economy and central planning is the model of macroeconomic control. However, these arguments were not mainstream and in fact became labelled as unofficial because 'socialist market economy' had been officially accepted as the goal of reform.

\section{Experience and lessons}

Economic reform in China has had remarkable results. It is not possible to list in detail every achievement, but they can be summarised. First, the pure public ownership structure has been replaced by a multi-ownership structure with different economic elements. Second, the market mechanism has played a critical role in certain important areas and the construction of a competitive market structure has advanced dramatically. Third, the use of indirect control has been the core of macroeconomic management; economic rather than administrative measures are now used due to various reforms in public finance, taxation, banking and investment. There have been significant substantial changes in the labour market and with respect to income distribution. Essentially, a multi-dimensional framework has been put in place.

Economic reform and economic development go hand in hand; they can mutually advance each other. Prezeworski (1991) argues that at the beginning of reform, whether it is gradual or radical, the decline in the level of output and consumption is inevitable and therefore, output growth has to be sacrificed. He states that the only difference is that it declines and picks up more quickly under radical reform than under gradual reform. This is illustrated in Figure 9.3. S denotes the start of reform, $R$ and $G$ represent radical and gradual reform, respectively.

The experience in China was totally different to that described by Prezeworski. Economic reform and development occurred simultaneously (Figure 9.4). China experienced a long period of rapid economic growth. The average growth of GDP in China between 1978-96 was 9.8 per cent; in the period 1991-96, average growth was 11.8 per cent. Although the two years that followed 1996 had lower growth rates, the annual average for the past twenty years is still above 9 per cent. Every single economic reform in China, whether in the rural or urban sector, has aimed to achieve economic growth through improvement in incentives. New reforms were only introduced when the success of former ones become apparent. This 
Figure 9.3 The tradeoff between economic reform and economic development

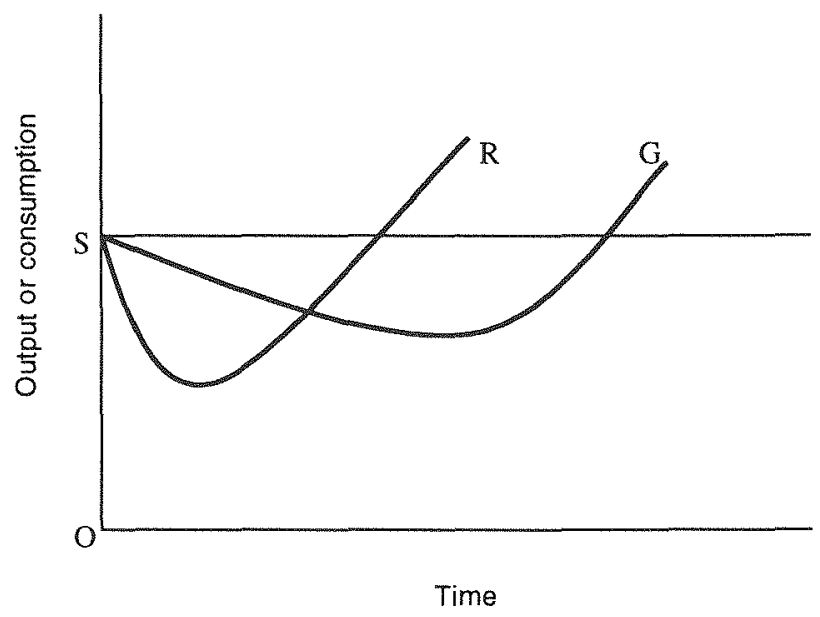

Notes: $S, G$ and $R$ dentoe the start of reform, gradual reform and radical reform, respectively.

approach applied to the implementation of the rural household production responsibility system, price reform for agricultural products, policies that encouraged the development of township and village enterprises (TVE) and non state-owned sectors, state-owned enterprise (SOE) reform in the urban sector, reform in retaining of foreign exchange earnings, and the establishment and development of special economic zones (Lin et al. 1994).

Without rapid economic growth, it would be impossible to make the rich richer and bring 0.2 billion people out of poverty; that is, raise the overall standard of living (World Bank 1997d). It was officially estimated that the population below the poverty line had dropped substantially from 0.25 billion in 1978 to 6 million in 1996 ( $\mathrm{Li}$ and Zhao 1997). An important feature of economic reform in China to date has been that economic growth and reform have gone hand in hand, forming a 'virtuous cycle'. This should be regarded as an important success of the reforms in China thus far. 
Figure 9.4 Economic reform and economic development: a 'virtuous cycle'

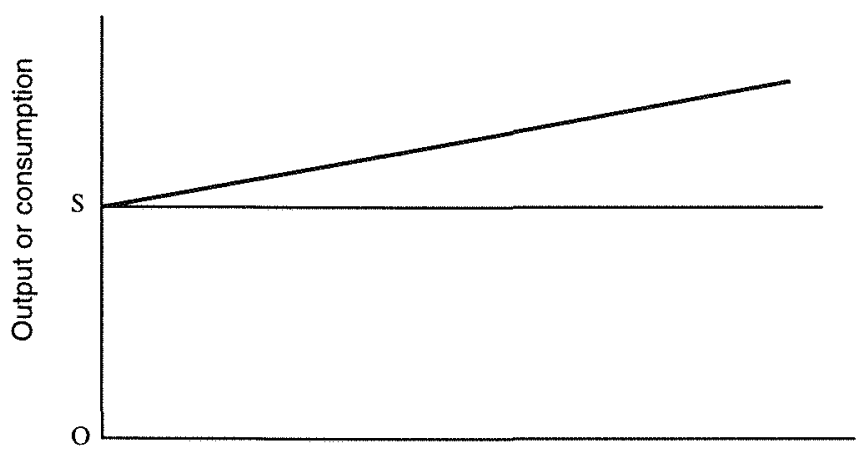

Time

Another important lesson from China's economic reform is that gradualism has reduced the costs and risks associated with reform. There is heated debate on the pros and cons of gradualist versus radical reform (Wu 1996). However, with the exception in the early 1980 s of rural sector reform, which had some elements of radicalism, China's reform can be broadly regarded as gradualist. In the rural sector, it took only two years-from September 1980 when the Central Planning Committee announced its desire to further strengthen the rural household production responsibility system, to autumn 1982-for the three-tier ownership structure under the commune system to be replaced by the rural household production responsibility system. This can be regarded as radical reform. But this was only part of the whole package of rural reform. Other aspects, including price reform and reform of the urban sector, can be regarded as gradual reform. Taking into account China's particular social and economic environment, this gradual reform can be regarded as successful. Harvard Professor J. Sachs, the proponent of radical reform in Eastern Europe and the former Soviet Union, agreed that gradual reform in China had been successful when he came to China in the early 1990 s. Professor W. Brus, of Cambridge 
University, who had suggested a so-called 'package' reform (radical reform) in his visit to China in the early 1980 s to avoid the friction resulting from the two-tier price system, agreed with Sachs when he also visited China in the early 1990 s.

There are two main areas in which gradual reforms have been successful. The first is in price reform, due to the introduction of the twotier price system. This system allows the prices of those goods and services under planned control to be adjusted gradually to match the market price. Although friction costs have resulted from this transitional reform, it has been less risky than radical price reform, in which market prices are applied to all goods and services prices at once.

The other particular success has been the gradual reform in ownership structure. Non state-owned enterprises were allowed to be established first. This increased the size of the non-SOE sector, and had a very positive impact on economic growth. So-called 'incremental' reforms were consistent with reducing the extent of central planning and with the transition from dual to modern economy (Fan 1996). They also demonstrate that reform and growth go hand in hand.

Price reform in the rural sector was a micro version of price reform in China. In the rural sector, collective ownership of land has been retained, but farmer's rights and responsibilities are now clear since the leasing period is long ( 15 years initially with an extension of a further 30 years). Figure 9.5 provides a broad picture of the benefits to farmers of price and ownership reform in the rural sector. Farmers had to sell to the government all the remaining grains and other important agricultural products at a very low price before the reform. The benefit is the area ACDF. After reform, the additional benefit to farmers is the area HJAC. This area can be decomposed into two parts: one that arises from 'price adjustment' within the planned price framework, area HIAB; the other that from 'price release', area IJBC. 'Price adjustment' entailed the government gradually increasing the planned purchase price and changing the relative price of agricultural goods to manufactured goods (depicted by the three little arrows in Figure 9.5); while 'price release' involved the gradual reduction of the quota that farmers were required to sell to the government. The reduction of the quota enabled farmers to sell part of their produce in the market at market prices (as shown by arrow 1 in Figure 9.5). 'Price release' in fact implies alteration of the price mechanism, from planned pricing to market pricing. The policies behind rural price reform were thereafter introduced as part of many urban sector reforms. 


\section{Figure 9.5 Price and ownership reform in the rural sector}

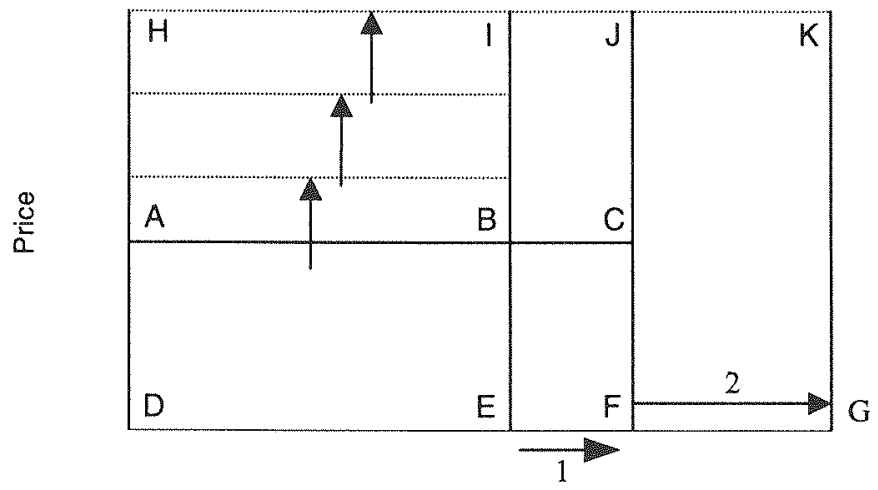

Output

Source: Author's calculations.

Ownership reform in the rural sector had significant effects. For example, total agricultural production increased by 42.2 per cent during the period from 1978 to 1984 (as shown by arrow 2 in Figure 9.5), of which 46.9 per cent is from the increase in productivity due to the introduction of the rural household production responsibility system. The success of economic reform in the rural sector not only increased total output but also benefited farmers greatly as they were able to sell their produce at a higher price than in the planned economy. This is shown as area JFKG in Figure 9.5. The success of the development of the non state-owned urban sector and rural TVEs can be attributed to the gradual 'incremental' nature of reform.

There are several lessons to be learned from economic reform in China in the past 20 years. The economist Xue Muqiao points out that the shock therapy of price reform in 1988 and the contract system introduced to SOEs in the second half of 1980 s to early 1990 s were 
two policies from which lessons have been learned. He regarded these two policies as 'going astray' (Xue 1998).

Price reform was introduced suddenly in June 1988 (hence the label 'shock therapy'). The justification for such price reform at the time was that 'long pain is no better than short pain', and that market prices should be put in place at once. The macroeconomic environment was very unfavourable for such policies: inflation was very high (18.5 per cent) and friction from dual pricing was at its worst (for example, the planned price for steel was 700 yuan per tonne while the market price was 1800 yuan per tonne). Implementing price reform in these circumstances was impractical. When the news of discussions about radical price reform was released to the media in August 1988, there was a nationwide run on the banks and panic-buying by consumers. The incident ended ideas of further speeding up the pace of price reform, and lent support to gradual price reform. Of course, the difficulties in putting market prices in place at once did not cast doubts on the necessity of price reform. The ultimate objective of the two-tier price system was to achieve a unified market price. However, there were lessons to be learned about the conditions under which a dual price system could be merged into a market price system. The first is that the difference between the planned and market price should not be too large. The planned price should gradually approach the market equilibrium price through adjustment. This ensures that the friction of price reform is minimised. Second, the goods and services whose prices are determined by the market should account for a large proportion of total goods in the economy. Finally, the macroeconomic environment should be favourable, for example there should be an appropriate money supply and low inflation.

The second important lesson from China's economic reforms was the reform of the contract system for SOEs. The contract system was only trialled in certain areas and certain enterprises before 1986. In December 1986, the State Council announced 'certain regulations with regard to deepening enterprise reform and strengthening efforts to revitalise enterprises' momentum'. The contract system was then introduced nationwide. The basic ideas were fixing the bases, fulfilling planned quantities, retaining surpluses and earning additional income, and covering their own losses. Up until 1992 they had been contracted for two periods (three years for each contract period). In July 1992, the State Council announced regulations for reforming SOE's operating 
system and exposing SOEs to the market. It was after November 1993 when the Third Plenum of the $14^{\text {th }}$ Central Planning Committee meeting proposed to establish the so-called modern enterprise system that the contract system became history.

There are three different views about the contract system within SOE. The first views the system highly and regards it as the strategic direction of economic reform. The second views the contract system as a transitional phase. The last view does not give much credit to the system and even regards it as 'going astray'. Xue is of this view. Two things give weight to it. First, the operating mechanism of the contract system strengthened the vertical one-to-one bargaining relationship between government and firm. It did not strengthen the competitive horizontal relationship between firms and in fact retained the bargaining relationship of the centrally planned system, and therefore was not consistent with market-oriented reform. In the centrally planned economic system SOEs bargained with the government over input and output quotas while under the contract system they bargained over the base for which the firm should deliver profits to the government. Second, under the contract system the government was able to maintain constant revenue in the short run. However, in the long run this was not guaranteed because there was no comparable, unified regulatory framework. In the bargaining process, the firm had incentives to bargain while the government officials did not. It became popular belief that the firm was responsible for profits but not losses. This is the key to understanding the loss of state capital. The contract system in name separated ownership from operation and appeared to be able to protect state capital. In fact, it reduced state capital. This was labelled by some as 'silent privatisation'. It appeared to be inconsistent with the original idea of protecting the state's ownership. As the loss of state capital and the extent of losses by SOEs became widespread, the contracts could no longer be maintained. This was pointed out by Xue: 'The direction and emphasis of SOE reform should gradually change to separation of government and enterprises and system innovation. The SOEs should become commodity producers and operators who have independent accounting, autonomy for operating, responsibilities for profits and losses, equal opportunity to compete and to be the winner through excellence or the loser by being inferior'. The contract system could not resolve these problems and therefore stunted the reform of SOEs (Xue 1998). 


\section{The challenges ahead}

Although the economic reforms in China have been very successful since their beginnings twenty years ago, there are still considerable challenges ahead.

The pace of reform represents a significant challenge. The distinction between gradual and radical reform is not clear-cut. There is no consensus about which approach is best. Previous reforms have had success through gradual reform where lower risk and costs were ensured. However, this approach solved issues that were relatively easy to deal with anyway, but left difficult issues unresolved. The most difficult reforms are still incomplete. Examples include reform of SOEs, financial and banking system reform, housing system reform and social security system reform. Perhaps gradual reform is not the optimal way to alter these systems; a more radical approach may be the answer. The economic recoveries of those economies that underwent the 'big bang' approach would support this view.

A challenge of further reform is to ensure balance is maintained. It becomes increasingly important to maintain a balance between three aspects: economic reform, economic development and social stability. Some economists emphasise the importance of social stability and propose that economic reform should only go ahead if it will not jeopardise social stability. Controlling inflation is the first priority of economic policy. Other economists emphasise economic reform and development and argue that social stability can only be achieved through economic development. Growth and employment are their first concerns in economic management. The way to achieve the right balance is by understanding the short and long-term goals and China's current economic and social environment. The relationship between SOE reform and social security system reform is typical of where it is important to distinguish short and long-term interests. In the early 1990s, 'breaking three irons (iron chair, iron bowl and iron wage)' was the target of SOE reform. Due to the lack of an adequate social security system at that time, reform measures had to be halted in order to avoid massive unemployment. Several years after that reform, the problems that had led to the policy of 'breaking three irons' appeared again. The issues remain, to some extent, unresolved. Reform of the social security system is an important issue and necessary in tackling urban unemployment. SOE reform and social security reform need to be coordinated. Only in 
this way can economic reform proceed while maintaining social and economic stability in both the short and long run. Recently, the concept of sustainable development has been widely accepted. It is important to ensure that economic reform and development go hand in hand in a sustainable way.

It is also important to maintain a well balanced relationship between different reform programs. This issue was first raised at the beginning of reform but is more important at this stage. Maintaining a balance does not mean that all the reforms should be implemented simultaneously. In fact, previous reform programs have been carried out sequentially. For example, rural sector reform preceded urban sector reform and price reform preceded ownership reform.

However, the order of the reforms should be such that they can effectively help each other. This applies to economic reform in every aspect. With respect to current reforms, ownership reform is lagging behind market reform while factor market reform is lagging behind product market reform. These problems will be solved gradually. The degree of marketisation that has been achieved in China is very impressive. For example, 60 to 70 per cent of goods and services currently have their price determined by the market. The degree of marketisation of social retail sales of goods and services has reached 92.5 per cent (Wen 1998). Due to the lag of ownership reform, many SOEs are facing difficulties and this in turn has become the stumbling block of finance and banking reform. It is estimated that China's SOEs have more than 1,000 billion yuan in bad debts, about 600 to 800 billion yuan worth of non-performing loans in bank accounts. Some economists therefore argue that without 'real enterprises' there will be no 'real banks' (Yang 1998).

There is a similar relationship between housing marketisation and labour marketisation. On the one hand, employees cannot afford expensive housing. On the other hand, those houses sold to employees at relatively low prices are not allowed to enter the market. The immobility of residential housing restrains the mobility of labour. This has become another stumbling block for SOE reform. The various difficulties of reform are intertwined. To proceed, the knot must be disentangled.

There is also the relationship between economic reform, political reform and other non-economic factors. As economic reform deepens, the need for political, moral and cultural reforms arises. It has been one of the characteristics that economic reform precedes political reform in 
China. This has its advantages. However, almost no one would argue that economic reform can proceed without political reform, or that political reform can be delayed indefinitely.

The relationship between the transformation of SOEs operational mechanism and that of government administrational functions is a typical example of the link between economic and political reform. One of the many important tasks of SOE reform is to separate SOEs from government organisation in order that SOEs become true market identities. It is obvious that it is impossible for SOEs to achieve this themselves. The transformation of SOEs' operational mechanism and shifts of government administrational functions are two sides of the same coin. When SOE reform deepens, shifting government administrational functions will be the key to further reform. Without the transformation of these functions, there is little hope for clearcut intellectual property rights, separation of government from enterprises and independent operation.

Of course, the transformation of government administrational functions does not imply that there is no role for government. The World Bank 1997 report indicates that good government is not a luxury. Without an effective government, sustainable social and economic development is impossible. In the case of market failure, government intervention is necessary, but by no means guaranteed.

Where market failure occurs, social moral intervention is also necessary. The importance of morals in economic reform and development is well known. A classic problem that was raised in Adam Smith's lifetime was how to deal with the relationship between economic man and moral man. This issue has drawn the increasing attention of academics in China. The moral factor will become increasingly important as economic reform deepens.

In summary, the challenges facing continued economic reform in China are serious. World Bank economist Joseph Stiglitz praises the achievements of economic reform in China but also points out that the Chinese government is facing massive difficulties and challenges. It is often said that economic reform is a system. This is true in an economic sense. If one takes into account the non-economic factors involved with economic reform, it can be regarded as an even bigger system. It is essential that China is ready for the challenges ahead and finishes this great and unprecedented project. 